DOI: 10.12731/2658-6649-2019-11-5-2-129-133

УДК 575.174.015.3

\title{
ИССЛЕДОВАНИЕ ВКЛАДА ПОЛИМОРФНОГО ВАРИАНТА ГЕНА ТGFВ В ФОРМИРОВАНИЕ ПОВРЕЖДЕНИЙ ХРОМОСОМ У ШАХТЕРОВ КУЗБАССА
}

Соколова А.О., Минина В.И.

Изучены ассочиачии полиморфного варианта rs1800469 гена TGFß с повреждениями хромосом у шахтеров Кузбасса. Выявлено повышение частоты аберраций у шахтеров, по сравнению с контрольной группой ( $p=0,000001)$. Показано увеличение частоты одиночных фрагментов у носителей генотипов ТT и CT, а также хроматидных обменов у обладателей генотипа TT.

Ключевые слова: хромосомные аберращии; гены контроля клеточного ичикла и апоптоза; шахтеры; TGFß.

\section{RESEARCH OF THE POLYMORPHIC VARIANTS OF TGFB CONTRIBUTION IN FORMATION OF CHROMOSOMAL DAMAGE OF KUZBASS MINERS}

\section{Sokolova A.O., Minina V.I.}

The effect of polymorphic variant of TGF $\beta$ gene on chromosome damage of Kuzbass miners was studied. The frequency of chromosomal aberrations among miners was increased (compared with the control group, $p=0,000001$ ). We discovered that TGF $\beta$ gene polymorphism increases the frequency of chromosomal damage (chromatide exchanges, single fragments) among miners.

Keywords: Chromosome aberrations; cell cycle control and apoptosis genes; coal miners; TGF $\beta$

\section{Введение}

Известно, что в формировании цитогенетических нарушений, возникающих вследствие воздействия мутагенных факторов, могут играть роль индивидуальные молекулярно-генетические особенности организма. Ранее было показано, что носительство определенных генетических вариан- 
тов может быть связано с формированием хромосомных аберраций (XА) различных типов [1]. В связи с этим, появляется актуальность изучения систем, обеспечивающих поддержание генетического гомеостаза у работников, подверженных высокой генотоксической нагрузке. Данная работа посвящена анализу полиморфного варианта гена $T G F \beta$ (rs 1800469).

Ген $T G F \beta$ кодирует полифункциональный цитокин, участвующий в регуляции процессов пролиферации, дифференцировки, миграции и апоптоза, а также в поддержании целостности генома [2].

Целью исследования являлось выявление особенностей индивидуальной чувствительности генома к воздействию генотоксических факторов производственной среды у шахтеров Кузбасса. Задачи исследования: выявить влияние производственных факторов на частоту и спектр хромосомных аббераций у шахтеров Кузбасса; исследовать взаимосвязь полиморфного варианта $r s 1800469$ гена $T G F \beta$ и хромосомными аберрациями у рабочих угледобывающего производства.

\section{Материалы и методы исследования}

Было обследовано 344 шахтера, работающих в шахтах Березовская и Первомайская Кемеровской области. Материалом для исследования служила цельная периферическая кровь. Подготовку препаратов хромосом и учет аберраций хромосом проводили в соответствии с требованиями, неоднократно описанными ранее [3]. ДНК выделяли из периферической крови стандартным методом фенольно-хлороформной экстракции. Типирование локуса TGF $\beta$ (rs 1800469) проводили методом аллель-специфической ПЦР (наборы НПФ «Литех», г. Москва). Статистическую обработку результатов вели с использованием программы «Statistica Trial 10.0»

\section{Результаты исследования}

Исследование уровней генетических повреждений показало, что у рабочих шахт частота аберрантных метафаз $(4,06 \pm 0,15 \%)$ была статистически выше, чем в контрольной группе $(1,8 \pm 0,08 \%$; $=0,000001)$, что говорит о мутагенном характере воздействия угольного производства.

Анализ повреждаемости хромосом в зависимости от генотипов полиморфного локуса $r s 1800469$ гена $T G F \beta$ выявил отличия между генотипами СТ $(2,23 \pm 1,98 \%)$ и ТТ $(2,89 \pm 2,2 \%$; $=0,02)$; ТТ $(2,89 \pm 2,2 \%)$ и $\mathrm{CC}$ $(2,17 \pm 1,98 \% ; p=0,03)$ у шахтеров для показателя одиночные фрагменты. Также были выявлены отличия по показателю хроматидные обмены между генотипами СТ $(0,03 \pm 0,17 \%)$ и ТT $(0,09 \pm 0,22 \%$; $\mathrm{p}=0,008)$. 


\section{Обсуждение}

Вопрос влияния различных генотипов $T G F \beta$ на уровень ХА еще недостаточно исследован. Santovito с коллегами установили, что носители минорного аллеля Т и генотипа СТ имели более низкий уровень сестринских хроматидных обменов по сравнению с обладателями других вариантов $T G F \beta[4]$. В то время как в ходе нашего исследования было выявлено повышение ряда цитогенетических нарушений у носителей аллеля $\mathrm{T}$ и генотипов ТТ и СТ. Однако, анализ литературы относительно влияния генотипов исследуемого полиморфзма на развитие различных заболеваний показал, что носители аллеля Т и генотипа СТ имели значительно повышенный риск развития ишемического инсульта, а также геморрагического и неустановленного инсульта [5].

Результаты данной работы позволят расширить имеющиеся представления о формировании индивидуальной чувствительности генетического аппарата человека к воздействию генотоксических факторов, а также, при более детальном исследовании, сформулировать рекомендации для работников угледобывающего производства в соответствии с их генетическими характеристиками.

\section{Заключение}

Производственная среда угольных шахт оказывает негативное воздействие на геном рабочих. Причем наиболее высокую чувствительность продемонстрировали рабочие с генотипом ТТ и СТ.

Таким образом, интенсивность накопления хромосомных аббераций зависит не только от факторов среды, но и от конститутивных особенностей организма, определеяемых, в том числе, генетическими полиморфизмами системы генов, обеспечивающих стабильность генома.

Информация о спонсорстве. Исследование было поддержано государственным заданием на 2019-2021гг № ГЗ 0352-2019-0011 (ЕГИСУ НИОКР AAAA-A17-117041410052-4).

\section{Список литературы}

1. Тимофеева А.А. Уровень хромосомных аберраций, доза активных рибоомальных генов и полиморфизм генов репарации ДНК у шахтеров Кемеровской области / А.А. Тимофеева [и др.]. // Медицина в Кузбассе. 2018. T. 17. № 3. C. 34-40.

2. Sporn M. TGF- $\beta$ : 20 years and counting // Microbes and Infection. 1999. Vol. 1, pp. 1251-1253. 
3. Carrano A.V., Natarajan A.T. International Commission for Protection Against Environmental Mutagens and Carcinogens / A.V., Carrano, A.T. Natarajan // Mutat Res. 1988. № 204(3), pp. 379-406.

4. Santovito A. Relationships between cytokine (IL-6 and TGF- $\beta 1$ ) gene polymorphisms and chromosomal damage in hospital workers / A. Santovito [et al.].// Journal of Immunotoxicology. 2016. Vol. 13(3), pp. 314-323.

5. Association of transforming growth factor- $\beta 1$ gene $\mathrm{C}-509 \mathrm{~T}$ and $\mathrm{T} 869 \mathrm{C}$ polymorphisms with atherosclerotic cerebral infarction in the Chinese: a case-control study / P. Zhongxing [et al.] // Lipids Health Dis. 2011. Vol. 10, pp. 100-108.

\section{References}

1. Timofeeva A.A. Uroven' hromosomnyh aberracij, doza aktivnyh riboomal'nyh genov i polimorfizm genov reparacii DNK u shahterov Kemerovskoj oblasti [Level of chromosomal aberrations, active ribosomal genes dose and polymorphism of DNA repair genes in miners of the Kemerovo region] / A.A. Timofeeva [i dr.] // Medicina v Kuzbasse. 2018. T. 17. № 3. S. 34-40.

2. Sporn M. TGF- $\beta$ : 20 years and counting // Microbes and Infection. 1999. Vol. 1. R. 1251-1253.

3. Carrano A.V., Natarajan A.T. International Commission for Protection Against Environmental Mutagens and Carcinogens / A.V., Carrano, A.T. Natarajan // Mutat Res. 1988. № 204(3). R. 379-406.

4. Santovito A. Relationships between cytokine (IL-6 and TGF- $\beta 1$ ) gene polymorphisms and chromosomal damage in hospital workers / A. Santovito [et al.]. // Journal of Immunotoxicology. 2016. Vol. 13(3), pp. 314-323.

6. Association of transforming growth factor- $\beta 1$ gene C-509T and T869C polymorphisms with atherosclerotic cerebral infarction in the Chinese: a case-control study / P. Zhongxing [et al.] // Lipids Health Dis. 2011. Vol. 10, pp. 100-108.

\section{ДАННЫЕ ОБ АВТОРАХ}

Соколова Анастасия Олеговна, магистрант

Федеральное государственное бюджетное образовательное учреждение высшего образования Кемеровский государственный университет

ул. Красная, 6, г. Кемерово, 650043, Российская Федерачия n_sov96@mail.ru

Минина Варвара Ивановна, г.н.с. Федерального исследовательского центра угля и углехимии СО РАН, д.б.н., доцент 
Федеральный исследовательский центр угля и углехимии СО РАН пр-т Советский, 18, г. Кемерово,650000, Российская Федераџия vminina@mail.ru

DATA ABOUT THE AUTHORS

Sokolova Anastasiya Olegovna, M.S. of biological sciences

Kemerovo State University (KemSU)

6, Krasnaya st., Kemerovo, 650043, Russian Federation

n_sov96@mail.ru

ORCID: 0000-0001-9967-0562

Minina Varvara Ivanovna, a leading researcher of Federal Research Center of Coal and Coal Chemistry SB RAS, Ph.D. of biological sciences, docent Federal Research Center of Coal and Coal Chemistry SB RAS

18, Soviet ave., Kemerovo, 650000, Russian Federation vminina@mail.ru

ORCID: 0000-0003-3485-9123 